\title{
Research on Teaching Methods and Means of Civil Engineering in Vocational Colleges
}

\author{
Na Li, Xiaowen Bian, Chengjie Luan, Wei Pan, Liyan Gao \\ Binzhou Polytechnic, Binzhou,256603 China \\ 411245815@qq.com
}

Keywords: vocational colleges; civil engineering; teaching methods and means

\begin{abstract}
This paper takes the civil engineering in vocational colleges as the research object. It analyzes the social responsibility of vocational education under the new situation of economic development. The paper summarizes the two major problems facing the civil engineering majors in vocational colleges, which are student issues and traditional education issues, and asserts that the reform of teaching methods and means is imperative. On the basis of practical argumentation, the paper gives corresponding suggestions on the reform of teaching methods and means from five aspects: student subject, informatization teaching, project-driven, school-enterprise cooperation, evaluation mechanism, which provide reference for improving teaching quality.
\end{abstract}

Vocational education is an important part of our education system. For a long time, vocational education has been devoted to cultivating applied talents for the country, which are oriented to the first production line and services management at the grass-roots posts. In June 2014, the State Council issued twenty-eight important guidelines in the "Decision on Accelerating the Development of Modern Vocational Education", which emphasized the need to "innovate and develop higher vocational education." In recent years, China’s economic construction has developed rapidly, and professional education has also made tremendous progress. Under the new economic situation, how to respond to the country's call for developing vocational education is an issue that every educator in a vocational college should meditate deeply. For the first-line teachers, we must start from the grass-roots education and teaching, innovate and improve education methods and means to improve the teaching level. Only in this way can we better serve the country's economic construction and cultivate high-quality skilled talents for the society.

This paper takes the civil engineering as an example to analyze the reform of teaching methods and means in vocational education. In recent years, with the development of the construction industry, the demand for professional talents in the civil engineering industry has remained high. The construction industry often requires a large number of grassroots workers. Compared with the traditional construction industry, the mechanization and intellectualization of the modern construction industry are increasingly improving, and the requirements for the quality of laborers are also growing. Skilled personnel with a certain theoretical knowledge and professional qualifications will become the main force in the construction industry. Vocational colleges should keep pace with the times, conform to social development, and serve the needs of society to cultivate the professional talents for civil engineering.

\section{The main dilemma of civil engineering teaching in vocational colleges}

At present, there are still some common problems in the education of civil engineering professionals in vocational colleges. The problems can be attributed to two major aspects of student issues and traditional teaching issues.

\subsection{Student aspects}

The students' problems are mainly reflected in the following three aspects. Firstly, the pre-school knowledge of vocational college students is relatively weak, while the curriculum of civil 
engineering has relatively high requirements for math and physical literacy, so it exists some certain difficulties in theoretical teaching. Secondly, during the previous learning stage, quite a few students from vocational colleges did not have developed good study habits, and even had a feeling of school-weariness. How to reverse student's prejudice towards learning, guide students to rebuild learning interest, cultivate learning ability and learning awareness are major issues faced by professional teachers. At last, the students' the capacity for self-restraint and self-management needs to be improved, and civil engineering courses mostly have practical training and practice links, which puts forward higher requirements for the discipline organization, order maintenance and safety promotion of schools and teachers.

\subsection{Traditional teaching methods}

The main drawbacks of the traditional teaching methods are as follows. The first is that the participation of students in traditional classrooms isn't high. In traditional classrooms, teachers often adopt "cramming” teaching methods. According to the content of lesson plans, they teach the knowledge points which in the textbooks in sequence, and occasionally question in the classroom. This kind of one-way teaching means that students are like "audiences", and they watch the teacher's "performance". The overall participation of students is very low and the atmosphere in classroom is boring. Students are easily distracted, and it is difficult to cultivate interest in professional courses. It is obvious that students' "subject" status has not been exerted in such traditional classroom. At the same time, the degree of informatization in such classes is low and it is difficult to effectively use network resources. In the "Decision of the State Council on Accelerating the Development of Modern Vocational Education," it is clearly stated that the development of vocational education should "increase the level of informatization." With the development of information technology and the completeness of schools' infrastructure, the introduction of multimedia tools, online courses, and simulation software for civil engineering majors will greatly assist classroom teaching and improve students' interest and cognitive ability. But the traditional teaching methods has been difficult to synchronize with modern teaching means due to lacking of information technology and network resources. The third aspect is that the practice link is weak, and students have poor hands-on skills. Civil engineering courses need practicing, but the traditional teaching methods are often like empty talk, just use theory to explain the theory, using words to elaborate words, which can't effectively combine practical resources for project teaching. This makes students can't understand the theoretical knowledge deeply, and it is difficult to master practical skills to meet business needs.

Based on this, the teaching methods and means for civil engineering majors in vocational colleges must undergo in-depth reforms in order to respond to the country's decision to accelerate the development of vocational education and make the civil engineering talents meet the requirements of industry development, and it will constitute the basic guarantee for the professional skills and students' own development.

\section{Suggestions on the reform of teaching methods and means}

The reform of teaching methods and means for civil engineering majors in vocational colleges is imperative, which requires the educators to seriously study the twenty-eight key guiding opinions in the "Decision of the State Council on Accelerating the Development of Modern Vocational Education" and know clearly the talents demand for the development of the construction industry under the new era. At the same time, we should actively study the advanced concepts and teaching techniques of vocational education at home and abroad, and get it repeatedly argument, diligently summarized, and continuously improved in teaching practice and personnel training. The reform proposals for teaching methods and means for civil engineering in vocational colleges are summarized below.

\subsection{Exchange roles, pad class, and improve students' participation in teaching activities}

Give full play to students' subject-role, and actively guide students to participate in classroom 
teaching. Heuristic teaching can be conducted in the in the pad class. Throw the questions to the students before teaching new knowledge, let they think and explore, and lead the students to prepare in advance. Simultaneously, on the basis of the organization of the class discussion, teacher evaluate and answer questions, fully mobilize the students' interest in learning, create a positive and lively classroom atmosphere. For highly applied professional courses, such as construction engineering survey, students can demonstrate on the basis of full demonstrations by teachers, and improve students' participation by organizing competitions, eventually return classes to students.

\subsection{Using informatization teaching means and network resources to achieve mixed teaching}

The traditional method of teaching is nothing more than "a mouth, a book, a chalk, a blackboard". Although it is methodical and logical, and it conforms to the textbook, but the form so boring that it is difficult to inspire students' interest. In the modern classroom, teachers should be good at using multimedia devices to make the text live and let the pictures vivid. The hard-to-teach construction machinery can be demonstrated by animation. The hard-to-describe construction essentials that should be illustrated by the job video of the construction site. In addition, we should make full use of resources such as Micro-lecture, MOOC, simulation software, and online courses to assist teaching. Combine the traditional instructional teaching, board writing teaching with the modern teaching methods, and use the advantages to achieve the best teaching consequent.

\subsection{Emphasize practice link, conduct scene teaching, achieve project driving and task driving}

Integrate typical engineering projects to achieve the integration of actual projects and teaching resources. Using the "one-unity, three-division” characteristic teaching organization form, get the teaching of the core curriculum be concentrated on the typical engineering projects, and make the engineering project runs through the course, and realize the project-driven "one unity". Besides, adopt the teaching means of gradually progress to complete the "three divisions". Emphasize and stress the cultivation of practical abilities. For example, take the 50 typical work tasks of the dormitory construction project as the main line, conduct scene teaching, and adopts an integrated teaching model of "guidance, direction, implementation, evaluation, and practicing” in every task to achieve task-driven teaching.

\subsection{Combine industry standards with teaching standards, and integrate part-time and full-time teachers}

On the basis of school-enterprise, when some teaching activities will be organized, the formulation of teaching criterions should fully consider the standards of the construction industry and refer to occupational standards. Meantime, colleges and enterprises shall jointly conduct professional competence analysis, develop professional courses, and optimize teaching content by focusing on the typical tasks in the professional field. Only students who have been trained in this way can meet the needs of society and the job. In addition, we should actively employ the backbone of the construction industry, business elites as part-time teachers, get them impart professional knowledge and project experience. It fully makes up for the shortcomings of young teachers' lack of practical experience and realize the organic integration of part-time teachers and full-time teachers in teaching activities.

\subsection{Reform the assessment methods, and improve the comprehensive evaluation mechanism}

Usually, assessment methods and evaluation mechanisms are the link that teachers and students are very concerned about, and they are also quantitative indexes for the inspection of teaching conditions. Under the new teaching methods and means, the traditional assessment methods and evaluation mechanisms should be optimized and reformed. First of all, the form of the examination should be retained. However, the content of the rote learning should be reduced as much as possible when the subject is posed. It focuses on the comprehensive topics such as the design and verification of a building structure, the flowing construction of a project, and the calculation of the mix ratio of concrete before mixing. The students' ability to solve practical problems should be pay more attention to. Secondly, attach importance to process assessment, increase the proportion of 
usual performance in the results, and let the score reflect the student's learning status to a greater extent, rather than achieve high scores by assaulting before exams. Thirdly, the assessment modus should be diversified. The scene hands-on ability, comprehensive assignments, and course thesis can all be part of the assessment. Finally, the contents of the examinations and assessments should be integrated with the related professional qualification examinations in the construction industry, actively guide and encourage students to obtain relevant professional qualification certificates in the industry.

\section{Conclusion}

In general, the exploration of teaching methods and means for civil engineering majors in vocational colleges is a long-term and progressive process. It requires the joint efforts of educators, and requires the cooperation of society, enterprises, schools, and students, to achieve the excellent effect. In order to respond to the country's call for developing vocational education and to train high-skilled personnel who adapted to social development and industry needs, teachers should remain true to our original aspiration and forge ahead, and explore and develop on the road of education, and improve teaching quality in a comprehensive way.

\section{Acknowledgements}

Research and practice of training model of professional personnel in higher vocational engineering under modern apprenticeship (ZJXH2017202)

\section{References}

[1] Weiwen Mo, Guixia Huang. Exploration of Teaching Method Design for Teaching Reform of Secondary Vocational Education [J]. Science and Technology Innovation Herald, 2015(16):251.

[2] Hong Zhang. A Preliminary Study on the Reform of Classroom Teaching Methods in Secondary Vocational Schools [J]. Vocational Technology, 2011, 10.

[3] Fuyan Li. On the Integration of Traditional and Modern Teaching Methods and Means in the Teaching Reform of Professional Courses in Higher Vocational Colleges[J]. Journal of Liaoning Educational Administration Institute, 2015(12):76-77.

[4] Ling Li, Liben Pan. Research on Improving the Effectiveness of Classroom Teaching of Civil Engineering Specialty in Higher Vocational Education[J]. Contemporary Education Research and Teaching Practice, 2015(7): 238-239.

[5] Weiqi Zhang, Ruixue Wang, Xiaodong Yang. Innovating the Civil Engineering Teaching Model in Higher Vocational Colleges to Improve the Quality of Talent Cultivation[J]. Journal of Harbin Vocational \& Technical College, 2015(3):33-34.

[6] Guizhi Sun. Exploration and Practice of Teaching Methods and Means Suitable For Higher Vocational Students[J]. China Modern Educational Equipment, 2013(3):73-74.

[7] Xiaorong Nie. The Optimal Combination of Classroom Teaching Methods And Means[J]. Education for Chinese After-school(Theory), 2015(5):47. 